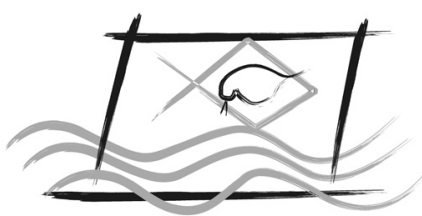

ECOTOX - BRASIL

\title{
Comparative Susceptibility of Freshwater Fish Species to Metals from Ultramafic Soils
}

\author{
E.C. Oliveira-Filho ${ }^{1,2}$, D.H.F. Muniz ${ }^{1}$, I.S. Freire 2 , F.G. Aquino ${ }^{3}$ \& L.R.M. Andrade ${ }^{3}$ \\ ${ }^{1}$ Laboratory of Ecotoxicology, Embrapa Cerrados, Rod. BR020, Km 18, Planaltina, DF 73310-970, Brazil. \\ ${ }^{2}$ Centro Universitário de Brasília, UniCEUB, SEPN 707/907, Asa Norte - Brasília - DF 70790-075, \\ ${ }^{3}$ Laboratory of Plant Biology, Embrapa Cerrados, Rod. BR020, Km 18, Planaltina, DF 73310-970, Brazil.
}

(Received June 26, 2012; Accept January 18, 2013)

\begin{abstract}
Soils derived from ultramafic rocks have a mineralogy rich in metals like $\mathrm{Co}, \mathrm{Cr}, \mathrm{Fe}$ and $\mathrm{Ni}$, and the process of extracting these metals from soil generates highly metallic waste. When disposed near of water bodies these residues pose a risk on the aquatic environment. Two fish species are used in ecotoxicity tests worldwide: Danio rerio (zebrafish), an Asian species, and Oreochromis niloticus (tilapia), an African one. However, Hyphessobrycon eques (mato grosso), a native of South America and found in Brazilian rivers, is as yet little used in ecotoxicity tests. The aims of this study were to evaluate the acute toxicity of the metals $\mathrm{Co}, \mathrm{Cr}, \mathrm{Fe}$ and $\mathrm{Ni}$ to the fish $D$. rerio, O. niloticus and H. eques, and compare its susceptibility. Tests were conducted following the recommendations of the Brazilian Association for Technical Standardization (ABNT). Stock solutions were prepared with the analytical reagents $\mathrm{CoCl}_{2} \cdot 6 \mathrm{H}_{2} \mathrm{O} ; \mathrm{K}_{2} \mathrm{Cr}_{2} \mathrm{O}_{7} ; \mathrm{FeCl}_{3} \cdot 6 \mathrm{H}_{2} \mathrm{O}$ e NiCl $.6 \mathrm{H}_{2} \mathrm{O}$. The quantification of metals was carried out in the stock solutions by ICP-AES. The dilution water used was synthetic softwater pH 7.3 \pm 0.1 , hardness $43 \mathrm{mg} \mathrm{L}^{-1}$; DO $95 \%$ and temperature $25 \pm 1^{\circ} \mathrm{C}$. To perform static tests 10 fish from each species were exposed for 96 hours, in duplicate, to different concentrations of the metals tested. The measured $96-\mathrm{hr}$ initial lethal concentrations LC(I) ${ }_{50}$ of metals Co, Cr, Fe and $\mathrm{Ni}$, calculated by the Trimmed Spearman Karber method, were 35.7, 35.9, 5.6 and $15.0 \mathrm{mg} \mathrm{L}^{-1}$ for D. rerio, 79.8, 32.6, 8.8 and $49.7 \mathrm{mg} \mathrm{L}^{-1}$ for $O$. niloticus and 104.1, 23.7, 8.5 and $34.5 \mathrm{mg} \mathrm{L}^{-1}$ for $H$. eques, respectively. The data showed that $D$. rerio has greater susceptibility to the metals tested, which justifies its increased use as a test species, except concerning $\mathrm{Cr}$, for which $H$. eques was the most sensitive species.
\end{abstract}

Keywords: ecotoxicity; heavy metals; mining; cobalt; chromium; iron; nickel

\section{Suscetibilidade Comparativa entre Espécies de Peixes de Água Doce a Metais de Solos Ultramáficos}

\section{Resumo}

Os solos derivados de rochas ultramáficas tem uma mineralogia rica em metais como $\mathrm{Co}, \mathrm{Cr}, \mathrm{Fe}$ e $\mathrm{Ni}$, e o processo de extração desses metais do solo gera um resíduo altamente metálico que quando disposto próximo a corpos hídricos pode apresentar risco aos ambientes aquáticos. Duas espécies de peixe exóticas são amplamente utilizadas em testes de ecotoxicidade Danio rerio (zebrafish) e Oreochromis niloticus (tilápia). Todavia, Hyphessobrycon eques (mato grosso), uma espécie da América do Sul e encontrada em rios brasileiros, é ainda pouco utilizada nesses ensaios. O objetivo desse estudo foi avaliar a toxicidade aguda dos metais $\mathrm{Co}, \mathrm{Cr}, \mathrm{Fe}$ e Ni para os peixes D. rerio, O. niloticus e H. eques, e comparar sua suscetibilidade. Os testes foram conduzidos de acordo com as normas da Associação Brasileira de Normas Técnicas. Soluções estoque foram preparadas com os reagentes analíticos $\mathrm{CoCl}_{2} \cdot 6 \mathrm{H}_{2} \mathrm{O} ; \mathrm{K}_{2} \mathrm{Cr}_{2} \mathrm{O}_{7} ; \mathrm{FeCl}_{3} \cdot 6 \mathrm{H}_{2} \mathrm{O}$ e NiCl $2.6 \mathrm{H}_{2} \mathrm{O}$. A quantificação dos metais foi realizada nas soluções estoque por análise em ICP-AES. A água de diluição foi a água mole pH $7.3 \pm 0.1$, dureza $43 \mathrm{mg} \mathrm{L}^{-1}$; OD $95 \%$ e temperatura $25 \pm 1^{\circ} \mathrm{C}$. Para realização dos testes estáticos 10 peixes de cada espécie foram expostos por 96 horas, em duplicata, às diferentes concentrações dos metais testados. As concentrações letais iniciais medidas $\mathrm{CL}(\mathrm{I})_{50}$, em 96 horas, dos metais $\mathrm{Co}, \mathrm{Cr}$, $\mathrm{Fe}$ and Ni, calculadas pelo programa Trimmed Spearman Karber, foram 35,7; 35,9; 5,6 e 15,0 $\mathrm{mg} \mathrm{L}^{-1}$ para D. rerio, 79,8; 32,6; 8,8 and 49,7 mg.L para $O$. niloticus e 104,$1 ; 23,7 ; 8,5$ e $34,5 \mathrm{mg} \mathrm{L}^{-1}$ para $H$. eques, respectivamente. $D$. rerio foi mais suscetível aos metais testados, o que justifica seu maior uso como espécie teste, exceto para o $\mathrm{Cr}$, ao qual $H$. eques foi a espécie mais sensível.

Palavras-Chave: ecotoxicidade; metais; mineração; cobalto; cromo; ferro; níquel

*Corresponding author: Eduardo C. Oliveira-Filho, e-mail: eduardo.cyrino@embrapa.br 


\section{INTRODUCTION}

Metals are important contaminants of aquatic ecosystems and are widely used by humans in manufacturing processes and modern technology. The soils of the Barro Alto and Niquelândia Districts located in Goiás State (Brazil) originate in ultramafic serpentinized rocks. These rocks are primarily poor in $\mathrm{N}, \mathrm{K}$ and $\mathrm{P}$, and rich in metals, such as $\mathrm{Cr}, \mathrm{Ni}, \mathrm{Fe}$ and $\mathrm{Co}$, which in high concentrations are potentially toxic to living species (Echevarria et al., 2006; Garnier et al., 2009). All regions worldwide that have this kind of soil have been explored by mining industries, and the processes that extract minerals from them generate waste products that have traces of these toxic elements in their final complex composition. This waste can release toxic compounds into ecosystems, mainly in water and soil, and it can affect species' survival and environmental quality, presenting potential risks to human health.

A number of studies show the effects of metals on aquatic invertebrates (Ravera 1977; Bellavere \& Gorbi, 1981; Baral et al., 2006; Deleebeeck et al., 2007) and freshwater fish (Bellavere \& Gorbi, 1981; Dave \& Xiu, 1991; Velma et al., 2009), but data showing a comparison between the acute data of chromium, cobalt, nickel and iron to freshwater fish, including exotic and Brazilian native species, are rare. It should be pointed that in Brazil, ecotoxicological assays have been performed with native or exotic species, but the exotic zebrafish Danio rerio predominates (Bertoletti, 2009). Considering this, the aims of this study were to provide scientific information on the acute toxicity of chromium, cobalt, nickel and iron to Danio rerio, Oreochromis niloticus and Hyphessobrycon eques, and to compare the susceptibility of these three species to tested metals.

\section{MATERIAL AND METHODS}

The fish species tested and their respective taxonomic families were the exotic Zebrafish (Danio rerio; Cyprinidae; Hamilton, 1822) and Nile tilapia (Oreochromis niloticus; Cichlidae; Linnaeus, 1758); and the native Mato-Grosso (Hyphessobrycon eques; Characidae; Steindachner, 1882). D. rerio and $H$. eques were purchased from a commercial supplier in Brasilia, weighed 0.2 to 0.4 grams and had an average length of 2.0 to $3.0 \mathrm{~cm}$. O. niloticus were obtained from the local municipality's fish farm in Brasília, where breeding conditions are controlled and monitored constantly, and had an average weight of 2.0 to 3.0 grams and average length of 4.0 to $6.0 \mathrm{~cm}$. The fish were acclimatized to laboratory conditions for one week prior to testing.

Metal concentrations were obtained by serial dilutions of the reagents $\mathrm{NiCl}_{2} \cdot 6 \mathrm{H}_{2} \mathrm{O}$ (Pro Analysis grade, purity $97 \%$ from Vetec, Brasil), $\mathrm{FeCl}_{3} \cdot 6 \mathrm{H}_{2} \mathrm{O}$ (Pro Analysis grade, purity $97 \%$ from Vetec, Brasil), $\mathrm{CoCl}_{2} \cdot 6 \mathrm{H}_{2} \mathrm{O}$ (Pro Analysis grade, purity $98 \%$ from Carlo Erba, Italy) and $\mathrm{K}_{2} \mathrm{Cr}_{2} \mathrm{O}_{7}$ (Pro Analysis grade, purity $99 \%$ from Merck, Germany). Stock solutions of each reagent were prepared and after dilutions in test water final nominal concentrations were recalculated according to the amount of respective metal. At this moment a sample of each concentration was taken to analyze the measured initial concentrations, determined in inductively coupled plasma optical emission spectroscopy (ICP-OES). To guarantee quality assurance and quality control of determinations, we also used blanks, duplicates, and spiked samples. Calibration coefficients were maintained at least 0.999 before proceeding with samples.

Static acute assays lasting 96 hours were carried out as standardized by the Brazilian Association for Technical Standardization (ABNT, 2004). Tests were performed in $3000 \mathrm{~mL}$ beakers with synthetic soft water $(\mathrm{pH} 7.3 \pm 0.1$, hardness $43 \mathrm{mg} \mathrm{L}^{-1}$ as $\mathrm{CaCO}_{3}$ ), maintained at $25 \pm 1^{\circ} \mathrm{C}$ under a 16-h light/8-h dark cycle and without food. Twenty fish were exposed (10 per beaker) to each concentration and mortality was evaluated after 48 and 96 hours of exposure, and dead fish were removed daily. Negative control (synthetic soft water) beakers were included.

The Initial Lethal Concentrations to $50 \%$ of the Fish $\mathrm{LC}(\mathrm{I})_{50}$ values and their $95 \%$ confidence limits, after 48 and 96 hours of exposure, were determined by the Trimmed Spearman Karber method (Hamilton et al., 1977) for reagents, metals' nominal concentrations and metals' measured concentrations.

\section{RESULTS}

The main objective of this study was to compare the susceptibility of different freshwater fish to metals present in ultramafic soils. As expected, values of lethal concentrations to $50 \%$ of tested fish were higher for reagents than for metals in nominal or measured concentrations.

Table 1 presents the toxicity of metallic reagents tested with fish species. Although these data do not represent the metals' toxicity, several papers publish results using these metallic compounds as reference, providing vital information on the susceptibility of fish to standard chemicals and support for inter and intra-laboratorial studies.

Table 2 shows the toxicity of metals in nominal and measured concentrations to tested fish species. It should to be noted that there is a considerable difference between these two values, and this can explain the numerous discrepancies in acute toxicity data already published. However, it is important to observe that in almost all cases the obtained values to Nominal $\mathrm{LC}_{50} \mathrm{~s}$ are inserted in the confidence intervals of Measured $\mathrm{LC}_{50} \mathrm{~s}$.

As shown in Tables 1 and 2, Danio rerio was the most susceptible species, except regarding chromium, where Hyphessobrycon eques ranks higher. On the other hand, Oreochromis niloticus was generally the most resistant species, except for chromium, to which Danio rerio was the most one.

\section{DISCUSSION}

The obtained data indicate that $H$. eques, a native species, can be appropriate for investigating toxicity of water bodies 
Table 1 - Lethal concentrations $50 \%$ of metallic reagents in $\mathrm{mg} \mathrm{L}^{-1}$ to tested species after 48 and 96 hours of exposure.

\begin{tabular}{|c|c|c|c|c|}
\hline Reagents & Exposure & D. rerio & H. eques & O. niloticus \\
\hline \multirow{4}{*}{$\mathrm{CoCl}_{2} \cdot 6 \mathrm{H}_{2} \mathrm{O}$} & \multirow{2}{*}{$48-\mathrm{hr}$} & 282.8 & 692.8 & 1345.4 \\
\hline & & $(211.1-378.8)$ & $(443.7-1081.9)$ & $(745.7-2427.6)$ \\
\hline & \multirow{2}{*}{ 96-hr } & 186.6 & 544.5 & 475.7 \\
\hline & & $(118.3-294.3)$ & $(353.9-837.7)$ & $(263.3-858.3)$ \\
\hline \multirow{4}{*}{$\mathrm{K}_{2} \mathrm{Cr}_{2} \mathrm{O}_{7}$} & \multirow{2}{*}{$48-\mathrm{hr}$} & 162.4 & 123.1 & 141.4 \\
\hline & & $(109.8-240.4)$ & (96.1-157.8) & (99.6-200.8) \\
\hline & \multirow{2}{*}{ 96-hr } & 123.1 & 93.3 & 107.2 \\
\hline & & $(83.2-182.2)$ & $(68.9-126.4)$ & (72.4-158.6) \\
\hline \multirow{4}{*}{$\mathrm{FeCl}_{3} \cdot 6 \mathrm{H}_{2} \mathrm{O}$} & \multirow{2}{*}{ 48-hr } & 40.6 & 56.7 & 66.1 \\
\hline & & $(31.7-52.0)$ & $(49.5-65.0)$ & $(60.8-71.9)$ \\
\hline & \multirow{2}{*}{ 96-hr } & 29.7 & 45.1 & 57.8 \\
\hline & & $(16.5-53.6)$ & $(39.4-51.7)$ & $(49.5-67.5)$ \\
\hline \multirow{4}{*}{$\mathrm{NiCl}_{2} \cdot 6 \mathrm{H}_{2} \mathrm{O}$} & \multirow{2}{*}{ 48-hr } & 107.2 & 214.3 & 649.8 \\
\hline & & $(79.1-145.2)$ & $(158.2-290.4)$ & (507.1-832.7) \\
\hline & \multirow{2}{*}{$96-\mathrm{hr}$} & 81.2 & 162.4 & 237.8 \\
\hline & & $(63.4-104.1)$ & $(126.8-208.1)$ & $(131.8-429.1)$ \\
\hline
\end{tabular}

in areas near ultramafic soils, since a recent study (Oze et al., 2007) showed that, in these areas, the generation of aqueous $\mathrm{Cr}$ (VI) exceeds its retention in solids or its reduction to $\mathrm{Cr}$ (III). Furthermore, Cruz et al. (2008) also observed that $H$. eques was the most sensitive to potassium dichromate among three different Brazilian fish species.
For the toxicity between metals, iron was the most toxic and cobalt was the least toxic for all species. Chromium was the second most toxic, except to $D$. rerio, where nickel showed highest toxicity.

In comparison with other studies, Bertoletti (2009) obtained a nominal $96-\mathrm{hr} \mathrm{LC}_{50}$ of hexavalent chromium to D. rerio of $31.8 \mathrm{mg} \mathrm{L}^{-1}$ in softwater and Bellavere \& Gorbi (1981) a nominal 96-hr $\mathrm{LC}_{50}$ of $58.5 \mathrm{mg} \mathrm{L}^{-1}$ in hardwater. These results are very similar to the $\mathrm{LC}_{50} 96 \mathrm{~h}$ calculated in the present study for nominal $=49.9 \mathrm{mg} \mathrm{L}^{-1}$ and measured $=35.9$ $\mathrm{mg} \mathrm{L}^{-1}$ concentrations of chromium (Table 2). As a reference chemical, the toxicity of potassium dichromate was tested with $H$. eques by Cruz et al. (2008). These authors found a $\mathrm{LC}(\mathrm{I})_{50}$ of $130.8 \mathrm{mg} \mathrm{L}^{-1}$, after 96 hours of exposure, and in the present study the $96-\mathrm{hr} \mathrm{LC}(\mathrm{I})_{50}$ and $95 \%$ confidence limits of this chemical to $H$. eques was $93.3 \mathrm{mg} \mathrm{L}^{-1}$ (68.9-126.4). In a study with the guppy Poecilia reticulata in hardwater Khangarot \& Ray (1990) found a $\mathrm{LC}_{50}$ after 96 hours of 29.28

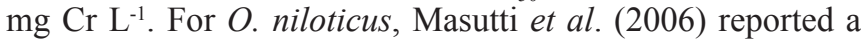
median 96-hr $\mathrm{LC}_{50}$ of $\mathrm{Cr}$ based on potassium dichromate of $133.5 \mathrm{mg} \mathrm{L}^{-1}$, a result similar to the $107.2 \mathrm{mg} \mathrm{L}^{-1}$ (72.4-156.6) obtained in the present study.

Regarding the toxicity of metallic chromium, the values shown in Table 2 are consistent with those obtained by Svecevicius (2006), who observed 96-hr LC50s between 28.5 and $49.3 \mathrm{mg} \mathrm{Cr} \mathrm{L}^{-1}$ for four European fish species. It should be noted that this European study was carried out in hardwater, low temperature and flow-through system exposure, parameters that can significantly interfere in the comparisons. With

Table 2 - Lethal concentrations 50\% (nominal and measured) of metals in $\mathrm{mg} \mathrm{L}^{-1}$ to tested species after 48 and 96 hours of exposure.

\section{Fish Species}

$\begin{array}{llll}\text { Metals Time } & \text { D. rerio } & \text { H. eques } & \text { O. niloticus }\end{array}$

\begin{tabular}{|c|c|c|c|c|c|c|c|}
\hline & & Nominal & Measured & Nominal & Measured & Nominal & Measured \\
\hline \multirow{4}{*}{$\mathrm{Co}$} & 10 & 71.2 & 54.1 & 174.51 & 132.5 & 333.2 & 287.7 \\
\hline & & $(53.2-95.4)$ & $(40.4-72.5)$ & $(111.7-272.5)$ & $(84.9-206.9)$ & $(184.7-601.3)$ & $(159.5-519.2)$ \\
\hline & & 47.0 & 35.7 & 137.1 & 104.1 & 92.4 & 79.8 \\
\hline & & $(29.8-74.1)$ & $(22.6-56.3)$ & $(89.1-211.0)$ & $(67.7-160.2)$ & $(68.2-125.2)$ & $(58.9-108.1)$ \\
\hline \multirow{4}{*}{$\mathrm{Cr}$} & 48 & 57.4 & 41.3 & 43.5 & 31.3 & 50.0 & 43.0 \\
\hline & & $(38.8-85.0)$ & $(27.9-61.1)$ & $(34.0-55.8)$ & $(24.4-40.1)$ & $(35.2-71.0)$ & $(30.3-61.0)$ \\
\hline & & 49.9 & 35.9 & 33.0 & 23.7 & 37.9 & 32.6 \\
\hline & & $(35.1-70.9)$ & $(25.3-51.0)$ & $(24.3-44.7)$ & $(17.5-32.1)$ & $(25.6-56.1)$ & $(22.0-48.2)$ \\
\hline \multirow{4}{*}{$\mathrm{Fe}$} & & 8.4 & 7.6 & 11.7 & 10.7 & 13.7 & 10.1 \\
\hline & $40-111$ & $(6.5-10.7)$ & $(5.9-9.7)$ & $(10.2-13.4)$ & $(9.3-12.2)$ & $(12.6-14.9)$ & $(9.2-10.9)$ \\
\hline & & 6.1 & 5.6 & 9.3 & 8.5 & 12.0 & 8.8 \\
\hline & $90-111$ & $(3.4-11.1)$ & $(3.1-10.0)$ & $(8.1-10.7)$ & $(7.4-9.7)$ & $(10.2-14.0)$ & $(7.5-10.3)$ \\
\hline \multirow{4}{*}{$\mathrm{Ni}$} & 4 & 26.5 & 22.8 & 52.9 & 45.5 & 121.6 & 114.2 \\
\hline & & $(19.5-35.9)$ & $(16.8-30.8)$ & $(39.1-71.7)$ & (39.6-61.7) & $(94.9-155.8)$ & $(89.2-146.4)$ \\
\hline & 0 & 20.0 & 15.0 & 40.1 & 34.5 & 52.9 & 49.7 \\
\hline & 30-111 & $(15.6-25.7)$ & $(11.2-20.1)$ & $(31.3-51.4)$ & $(26.9-44.2)$ & $(39.1-71.7)$ & $(36.7-67.4)$ \\
\hline
\end{tabular}


respect to iron, few studies have reported its acute toxicity to fish. Dalzell \& MacFarlane (1999) found a $96-\mathrm{hr} \mathrm{LC}_{50}$ of $28 \mathrm{mg} \mathrm{Fe} \mathrm{L}^{-1}$ to brown trout weighing 15 to 30 grams. This result is also similar to those obtained in the present research with smaller fish (Table 2). Other studies have focused on the use of $\mathrm{FeCl}_{3} \cdot 6 \mathrm{H}_{2} \mathrm{O}$ to purify wastewater samples, testing water samples, effluents or sludge from treatment plants. Sotero-Santos et al. (2007) observed non acute effects of ferric chloride sludge on $H$. eques. It should be noted that in these samples ferric salt is added for removal of phosphate ions and other organic matter. After complexation with these compounds and $\mathrm{FeCl}_{3}$ precipitation of larger particles occurs, modifying the metal bioavailability and protecting aquatic species from acute toxicity (Randall et al. 1999; Weltens et al. 2000; Van Anholt et al. 2002).

Nickel was the third most toxic of the metals tested. The 96-hr measured $\mathrm{LC}(\mathrm{I})_{50}$ to D. rerio was $15.0 \mathrm{mg} \mathrm{L}^{-1}$ (Table 1) and this is consistent with results from previous studies with fish. Although working with hardwater, Khangarot \& Ray (1990) found a similar result with Poecilia reticulata. These authors calculated a $\mathrm{LC}_{50}$ in 96 hours of $29.28 \mathrm{mg} \mathrm{Ni}$ $\mathrm{L}^{-1}$. For adults of Pimephales promelas in softwater $(48 \mathrm{mg}$ $\mathrm{L}^{-1}$ ) Hoang et al. (2004) found a $96 \mathrm{hr}-\mathrm{LC}_{50}$ of $8.4 \mathrm{mg} \mathrm{L} \mathrm{L}^{-1}$ and Pickering (1974) reported a nominal $96 \mathrm{hr}-\mathrm{LC}_{50}$ for this species ranging from 27 to $32 \mathrm{mg} \mathrm{L}^{-1}$ of nickel, in hardwater. Brix et al. (2004) observed a $96 \mathrm{hr}-\mathrm{LC}_{50}$ of $20.8 \mathrm{mg} \mathrm{L}^{-1}$ to rainbow trout in hardwater (hardness $91 \mathrm{mg} \mathrm{L}^{-1}$ ), Nebeker $e t$ al. (1985) estimated a $96-\mathrm{hr} \mathrm{LC} \mathrm{LC}_{50}$ of $10.0 \mathrm{mg} \mathrm{L}^{-1}$ in softwater (hardness $33 \mathrm{mg} \mathrm{L}^{-1}$ ) and Pane et al. (2003) calculated a 96-hr $\mathrm{LC}_{50}$ of $15.3 \mathrm{mg} \mathrm{L}^{-1}$ at a water hardness of $140 \mathrm{mg} \mathrm{L}^{-1}$.

About the acute effects of cobalt, its low toxicity in softwater has been described by Diamond et al. (1992), who found that the $\mathrm{LC}_{50}$ values for fathead minnows could not be calculated due to their low susceptibility to high concentrations of cobalt. In this experiment the authors defined the lethal concentration to $50 \%$ as being higher than $5.8 \mathrm{mg} \mathrm{L}^{-1}$. This effect was also reported by Dave \& Xiu (1991), who observed no mortality of embryos and larvae of $D$. rerio exposed for 9 days at concentrations up to $15.3 \mathrm{mg} \mathrm{Co} \mathrm{L}^{-1}$. Both of these studies reinforce the low toxicity of cobalt to freshwater fish, as observed in the present study, when compared with the other metals investigated.

The toxic effects of metals and metallic compounds depend on the rate and extent to which metals or compounds are transformed into a bioavailable form (Muniz \& Oliveira-Filho, 2006). In natural waters several factors can interfere with the toxicity of metals, including temperature, $\mathrm{pH}$, dissolved salts and complexation with organic matter (Sprague, 1995). Thus, the bioavailability of metals in natural water bodies may be different from that observed in standardized assay water and so any extrapolation of data should be done with caution in environmental management policies.

The acute toxicity results from the present investigation were generally consistent with those of previous acute studies involving fish species. The higher toxicity of iron and the lower toxicity of cobalt were the main data obtained. The comparison between the values of nominal and measured $\mathrm{LC}_{50}$ showed a significant relationship, because in almost all cases the nominal values could be inserted into the $95 \%$ confidence intervals of measured values.

\section{CONCLUSIONS}

Danio rerio was the most susceptible species except to chromium, and this information reinforces data from other authors and guidelines that recommend this fish for use in Brazilian ecotoxicity assays. Hyphessobrycon eques has been demonstrated to be the most sensitive to chromium, and its application to research in areas with ultramafic soils could be a promising alternative. On the other hand, Oreochromis niloticus, an indigenous and introduced species in Brazil, was the least acutely susceptible to the metals tested, but its size is better suited to tests involving biomarkers or the investigation of physiological effects. Finally, the results of this study indicate that the presence of these metals in aquatic ecosystems can significantly interfere with the distribution of species, mainly due to their high lethality to fish.

\section{ACKNOWLEDGEMENTS}

The team is grateful to $\mathrm{CT}$ - Mineral CNPq of the Brazilian Ministry of Science and Technology (Contract $n^{\circ}$ 409997/2006-4) and SEG-Embrapa for financial support.

\section{REFERENCES}

ASSOCIAÇÃO BRASILEIRA DE NORMAS TÉCNICAS [ABNT]. 2004, Ecotoxicologia aquática - Toxicidade aguda - Método de ensaio com peixes. NBR 15088. Rio de Janeiro: ABNT.

BARAL, A., ENGELKEN, R., STEPHENS, W., FARRIS, J. \& HANNIGAN, R., 2006, Evaluation of aquatic toxicities of chromium and chromium-containing effluents in reference to chromium electroplating industries. Arch. Environ. Contam. Toxicol., 50: 496-502. http://dx.doi.org/10.1007/s00244-0050068-x

BELLAVERE, C. \& GORBI, J., 1981, Comparative analysis of acute toxicity of chromium, copper and cadmium to Daphnia magna, Biomphalaria glabrata and Brachydanio rerio. Environ. Technol. Lett., 2: 119-128. http://dx.doi. org/10.1080/09593338109384031

BERTOLETTI, E., 2009, Sensibilidade de algumas espécies de peixes de água doce utilizadas no Brasil. J. Braz. Soc. Ecotoxicol., 4: 9-13. http://dx.doi.org/10.5132/jbse.2009.01.002

BRIX, K.V., KEITHLY, J., DEFOREST, D.K. \& LAUGHLIN, J., 2004, Acute and chronic toxicity of nickel to rainbow trout (Oncorhynchus mykiss). Environ. Toxicol. Chem., 23: 22212228. http://dx.doi.org/10.1897/03-38

CRUZ, C., CUBO, P., GOMES, G.R., VENTURINI, F.P., GUILHERME, P.E. \& PITELLI, R.A., 2008, Sensibilidade de peixes neotropicais ao dicromato de potássio. J. Braz. Soc. Ecotoxicol., 3: 53-55. http://dx.doi.org/10.5132/ jbse.2008.01.008

DAVE, G. \& XIU, R., 1991, Toxicity of mercury, copper, nickel, and cobalt to embryos and larvae of zebrafish, Brachydanio rerio. Arch. Environ. Contam. Toxicol., 21: 126-134. http://dx.doi. org $/ 10.1007 / \mathrm{BF} 01055567$ 
DALZELL, D.J.B. \& MACFARLANE, N.A.A., 1999, The toxicity of iron to brown trout and effects on the gills: a comparison of two grades of iron sulphate. J. Fish Biol., 55: 301-315. http:// dx.doi.org/10.1111/j.1095-8649.1999.tb00680.x

DELEEBEECK, N.M.E., MUYSSEN, B.T.A., DE LAENDER, F., JANSSEN, C.R. \& DE SHAMPHELAERE, K.A.C., 2007, Comparison of nickel toxicity to cladocerans in soft versus hard surface waters. Aquatic Toxicol., 84: 223-235. http://dx.doi. org/10.1016/j.aquatox.2007.03.025

DIAMOND, J.M., WINCHESTER, E.L., MACKLER, D.G., RASNAKE, W.J., FANELLI, J.K. \& GRUBER, D., 1992, Toxicity of cobalt to freshwater indicator species as a function of water hardness. Aquatic Toxicol, 22: 163-180. http://dx.doi. org/10.1016/0166-445X(92)90038-O

ECHEVARRIA, G., MASSOURA, S.T., STERCKEMAN, T., BECQUER, T., SCHWARTZ, C. \& MOREL, J.L., 2006, Assessment and control of the bioavailability of nickel in soils. Environ. Toxicol. Chem., 25: 643-651. http://dx.doi. org/10.1897/05-051R.1

GARNIER, J., QUANTIN, C., GUIMARÃES, E., GARG, V.K., MARTINS, E.S. \& BECQUER, T., 2009, Understanding the genesis of ultramafic soils and catena dynamics in Niquelândia, Brazil. Geoderma, 151: 204-214. http://dx.doi.org/10.1016/j. geoderma.2009.04.020

HAMILTON, M.A., RUSSO, R.C. \& THURSTON, R.V., 1977, Trimmed Spearman-Karber method for estimating median lethal concentrations in toxicity bioassays. Environ. Sci. Technol., 11: 714-719. http://dx.doi.org/10.1021/es60140a017

HOANG, T.C., TOMASSO, J.R. \& KLAINE, S.J., 2004, Influence of water quality and age on nickel toxicity to fathead minnows (Pimephales promelas). Environ. Toxicol. Chem., 23: 86-92. http://dx.doi.org/10.1897/03-11

KHANGAROT, B.S. \& RAY, P.K., 1990, Acute toxicity and toxic interaction of chromium and nickel to common guppy Poecilia reticulata (Peters). Bull. Environ. Contam. Toxicol., 44: 832839. http://dx.doi.org/10.1007/BF01702171

MASSUTI, M.B., ESPINDOLA, E.L.G., NOGUEIRA, A.M. \& SIMÕES, F.C.F., 2006, Sensibilidade a cobre e cromo por Oreochromis niloticus e Pistia stratiotes.J. Braz. Soc. Ecotoxicol., 1: 37-42. http://dx.doi.org/10.5132/jbse.2006.01.008

MUNIZ, D.H.F. \& OLIVEIRA-FILHO, E.C., 2006, Metais pesados provenientes de rejeitos de mineração e seus efeitos sobre a saúde e o meio ambiente. Universitas Ci. Saude, 4: 83-100. http://dx.doi.org/10.5102/ucs.v4i1.24

NEBEKER, A.V., SAVONEN, C. \& STEVENS, D.G., 1985, Sensitivity of rainbow trout early life stages to nickel chloride.
Environ. Toxicol. Chem., 4: 233-239. http://dx.doi.org/10.1002/ etc. 5620040214

OZE, C., BIRD, D.K. \& FENDORF, S., 2007, Genesis of hexavalent chromium from natural sources in soil and groundwater. Proc. Nat. Acad. Sci. USA, 104: 6544-6549. http://dx.doi.org/10.1073/ pnas.0701085104

PANE, E.F., RICHARDS, J.G. \& WOOD, C.M., 2003, Acute waterborne nickel toxicity in the rainbow trout (Oncorhynchus mykiss) occurs by a respiratory rather than ionoregulatory mechanism. Aquatic Toxicol., 63: 65-82. http://dx.doi. org/10.1016/S0166-445X(02)00131-5

PICKERING, H., 1974, Chronic toxicity of nickel to the fathead minnow. J. Water Pollut. Control Fed., 46: 760-765.

RANDALL, S., HARPER, D. \& BRIERLEY, B., 1999, Ecological and ecophysiological impacts of ferric dosing in reservoirs. Hydrobiologia, 395/396: 355-364. http://dx.doi. org/10.1023/A:1017046913027

RAVERA, O., 1977, Effects of heavy metals (cadmium, copper, chromium and lead) on a freshwater snail: Biomphalaria glabrata Say (Gastropoda, Prosobranchia). Malacologia, 16: 231-236.

SOTERO-SANTOS, R.B., ROCHA, O. \& POVINELLI, J., 2007, Toxicity of ferric chloride sludge to aquatic organisms. Chemosphere, 68: 628-636. http://dx.doi.org/10.1016/j. chemosphere.2007.02.049,

SPRAGUE, J.B., 1995, Factors that modify toxicity, pp. 1012-1051. In: G.M. Rand, (org.), Fundamentals of aquatic toxicology: effects, environmental fate and risk assessment, 1185p., Taylor \& Francis, Washington.

SVECEVICIUS, G., 2006, Acute toxicity of hexavalent chromium to European freshwater fish. Bull. Environ. Contam. Toxicol., 77: 741-747. http://dx.doi.org/10.1007/s00128-006-1126-4

VAN ANHOLT, R.D., SPANINGS, F.A.T., KNOL, A.H., VELDEN, J.A. \& WENDELAAR BONGA, S.E., 2002, Effects of iron sulfate dosage on the water flea (Daphnia magna Straus) and early development of carp (Cyprinus carpio L.). Arch. Environ. Contam. Toxicol., 42: 182-192. http://dx.doi.org/10.1007/ s00244-001-0001-X

VELMA, V., VUTUKURU, S.S. \& TCHOUNWOU, P.B., 2009, Ecotoxicology of hexavalent chromium in freshwater fish: a critical review. Rev. Environ. Health, 24: 129-145. http://dx.doi. org/10.1515/REVEH.2009.24.2.129

WELTENS, R., GOOSSENS, R. \& VAN PUYMBROECK, S., 2000. Ecotoxicity of contaminated suspended solids for filter feeders (Daphnia magna). Arch. Environ. Contam. Toxicol., 39: 315-323. http://dx.doi.org/10.1007/s002440010110 